\title{
Compound Words Used in Stephenie Meyer's Twilight
}

\author{
Ririn Dwi Cahyanti \\ ririndwic@gmail.com \\ MA Hidayatul Insan Palangka Raya \\ Jl. Sulawesi No. 7 Palangka Raya, Kalimantan Tengah, Indonesia
}

Received: February 5, 2016; Accepted: March 8, 2016; Published: March 25, 2016

\begin{abstract}
This study was aimed at describing the types, the function, and the meaning of the compound words used in Stephenie Meyer's Twilight. A qualitative method with the content analysis was applied in this study. The object of this study was compound words. For the data collection, it was used the techniques such as data collection, data reduction, data display, and conclusion drawing. This study was validated by using triangulation. The findings showed that there are 253 compound words. Based on the type of compound words, there are 5 compound words categorized as open form, 65 compound words categorized as hyphenated form, and 183 compound words categorized as closed form. Based on the function of compound words, there are 173 compound nouns, 13 compound verbs, and 67 compound adjectives. Referring to the meaning of compound words found from the contextual meaning, there are 140 words of the exocentric compound and 113 words of the endocentric compound.
\end{abstract}

Keywords: compound words, Twilight novel, content analysis

How to cite this paper: Cahyanti, R. D. (2016). Compound Words Used in Stephenie Meyer's Twilight. Journal on English as a Foreign Language, 6(1), 59-70.

Language is a tool of communication to sent ideas, feeling, and messages. In transferring of them, it cannot be denied the function of the language, the main function of the language is to share information among each other. It has been known that English is an international language. In English, there are many aspects that can be learned every time and there is no limit. For example, it may be related to linguistic aspects and linguistic skills. Linguistic aspect can be 
related to grammar, vocabulary, and pronunciation; meanwhile, linguistic skills refer to listening, speaking, reading, and writing.

In the linguistic unit, the learners should understand about grammar, vocabulary, and pronunciation. To talk about grammar, it clarifies about the rule of language. Vocabulary is related to the central part of the language. It is like an ammunition of gun. Meanwhile, pronunciation is related to sounds, how the words are pronounced. There are compound words, phrasal, clause, sentence, compound sentence, paragraph, essay, and thesis. In this study, it is investigated about compound words.

The term "word" is part of everyone's vocabulary. A good way of teasing apart the ingredients in the notion "word" is by explicitly contrasting them (McCarthy, 2002). A definite answer is not always possible, but there are enough clear cases to show that the distinction between compounds and phrases is valid. Consider the expressions a greenhouse, with its literal meaning, and a greenhouse, meaning a glass structure (not usually green in color!) where delicate plants are reared. There is a difference in sound corresponding to the difference in meaning: in the first expression, the main stress is on house, while in the second the main stress is on green.

Compound is a word formed by combining roots, and the much smaller category of phrasal words, that is items that have the internal structure of phrases but function syntactically as words. In many cases, compounds are easy to tell apart from phrases with two contents words. For instance, compounds may consist of two or more lexeme stems that are aligned in a single wordform, and, when a language does not allow phrases consisting of two aligned lexemes of those same word-classes, the combination must be a compound.

According to Haspelmath and Sims (2010), there are also a great many cases in which compounds are quite similar to phrases with a similar meaning, and then researchers or readers have to take a closer look in order to distinguish the two patterns. A compound word is a little bit difficult to know the exactly compound word in the texts, articles, journals or novels than knowing phrases, researchers or readers could know it is a phrase just by look at the position of the word in the sentences. But sometimes researchers or readers are confused to identify the words because phrases and compound words have quite similar meaning.

The difference between phrases and compound words is that compound word has classifying word depending on the function of the word in the sentences. According to Bauer cited by Aryana (2008), it states that the normal way of classifying compounds is by the function they play in the sentence as nouns, verbs, adjectives, and etcetera. Most longer compound, combinations of two elements, each of which may, in turn, can be compound (Aryana, 2008). In 
addition, Katamba cited by Aryana (2008) said that a compound adjective contains a noun followed by an adjective, an adjective followed by an adjective (derived from the past participle form of verb), and preposition by an adjective (derived from the present or past participle form of the verb).

The theory from Delahuntly, Garvey, Murty, and Katamba said that compound word has 3 forms: the closed form, compounds written as single words (newspaper, goldfish, highway); the hyphenated form, compounds that are hyphenated (mother-in-law, second-rate, court-martial); the open form, compounds written as separated words (end zone, high school, health care).

The study of compound words makes longer words more accessible and helps bridge the gap between single and polysyllabic word study. Through learning how the meaning of each morpheme contributes to the meaning of the compound word, students can develop an important word-attack strategy, increase their word-building skills, build vocabulary, reinforce spelling skills, and develop reading fluency. In learning those kinds of English learning, teachers and readers should use media to modify the bored strategy of teaching English in the class.

Media is one of the proponents of students learning. There are many media that can be used for this study, but the novel is chosen as media of this study. Limitation of second language learning media is described by a number of views of experts and relevant literature sources. According to Gagne, media is seen as any kind of a component within the student or students who can provide the motivation to learn. Briggs state that media is all the physical tools that can make the messages to communicate and stimulate children to learn. Of these limits concluded, media are all forms of communication tools that can be used to convey the message or information from a source or sources to students in order to stimulate the mind, feelings, interests and concerns in implementing learning activities (Indihari, 2012).

Artificial media (artificially) limited that the media are not yet made or created before the media used in learning. For example pictures, movies, videos, books, dictionaries or encyclopedias. The example of media learning in books is novel. The definition of a novel based on Kamus Besar Bahasa Indonesia (KBBI) cited by Ginting (2011) is a long prose essay containing the sequence a person's life story with people around the character to accentuate the character and nature of each offender.

Then Twilight novel tells a story that contains the sequence a person's life in fictitious and explains the character and nature of each offender through the story. A film adaption of Twilight was released in 2008. It was a commercial success, grossing more than 392 million dollars worldwide and an additional 157 million dollars from North American DVD sales, as of July 2009. 
Twilight was released in 2005 to rave reviews, quickly becoming a bestseller. An active member of the Church of Jesus Christ of Latter-day Saints, Meyer had eschewed strong sexuality in her writing, supplanting it with the florid sensuality-a draw for her numerous (and primarily female) reader.

Twilight was honored as a New York Times "Editor's Choice and Publishers Weekly Best Book of the Year." The following year, Meter published her sophomore effort, the sequel New Moon, and sold the film rights to Twilight. With the third and fourth installments, Eclipse in 2007 and Breaking Dawn in 2008), Meyer's series has sold more 250 million copies and has been translated into 37 languages. The books were also adapted for a film series amassing five installments, including The Twilight Saga: Breaking Dawn- Part 2, released in November 2012. Grossing nearly $\$ 200$ million domestically, the Twilight film series stars Kristen Stewart (Bella Swan), Robert Pattinson (Edward Cullen) and Taylor Lautner (Jacob Black).

This study was aimed at describing the types, the function, and the meaning of the compound words used in Stephenie Meyer's Twilight (Meyer, 2005). The study of compound words could hopefully help students as a learner as well, the other learners who learn about compound word from novel as their media teaching, and readers as students who attracted in twilight novel to know and understand about compound words in written perspective like open form, hyphenated form and closed form; function perspective like compound verbs, compound noun, compound adjectives, blend words; and meaning perspective like exocentric (headless), endocentric (headed) and co-ordinate (head-like), then can help readers identify about compound word easily. And also will give an idea for readers as a teacher to choose twilight novel as a media that can be taught in finding compound words in the class.

\section{METHOD}

The qualitative research design was applied in this study. According to Sugiyono (2010), in qualitative, the researcher is the researcher instrument itself. So it is suitable for this current study. Based on methodological perspective, qualitative research is a loosely defined collection of approaches to inquiry (Thompson, 1994).

The design used in the study is content analysis to identify compound words used in Twilight novel, to identify the types of compound words used in Twilight novel, to identify the function of compound words used in Twilight novel, and to identify the meanings of compound words used in Twilight novel. The techniques of data collection are through several steps as follows: identifying the compound words used in Twilight novel, analyzing the compound words used in Twilight novel, describing the compound words used 
in Twilight novel, and discovering the compound words which are in words class perspective, written perspective and meaning perspective used in Twilight novel.

In qualitative studies, the human investigator is the primary instrument for the gathering and analyzing of data. Lincoln and Guba cited by Aryana (2008) introduced the concept of human as an instrument to emphasize the unique role that qualitative the researcher play in the inquiry. Because qualitative research studies human experiences and situations, researchers need an instrument flexible enough to capture the complexity of the human experience, an instrument capable of adapting and responding to the environment (Ary, Jacobs, \& Sorensen, 2010).

The data that analyzed in this study are the compound words found in the "Twilight" novel written by Stephenie Meyer in the form of the book as the main source of the data in this study. This novel was released in the United States on October 5, 2005, and it is 498 pages in hardcover and 544 pages in paperback. It is the first story of a vampire and human love that makes readers curious about the end of their love story in different life. It contained compound words, the data analyzed are the compound words that are written by the author in the novel.

To collect the data in this study, it was used documentation, observation, test, interview, and questionnaire. The document was used as the way to collect the data, and the document is twilight novel. It is as mentioned that this study used content analysis utilizing some procedures to take the conclusion from the book or document (Gunawan, 2014).

\section{FINDINGS}

There are 253 words found in this novel. Furthermore, in the written perspective, there are 5 open form words, 65 hyphenated form words, and 183 closed forms words. In the word class perspective, there are 173 compound noun words, 13 compound verb words, and 67 compound adjective words. Meanwhile, in the meaning perspective, there are 140 words in exocentric compound and 113 words in the endocentric compound (See Table 1). 
Table 1. Type of Compound Words in Twilight Novel

\begin{tabular}{|c|c|c|}
\hline \multicolumn{3}{|c|}{ Open Form of Compound Words } \\
\hline 1. Giving birth & 3. Open book & 5. Take care \\
\hline 2. High school & 4. Police station & \\
\hline \multicolumn{3}{|c|}{ Hyphenated Form of Compound Words } \\
\hline 1. Baby-faced & 23. High-pitch & 45. Right-hand \\
\hline 2. Blow-dry & 24. Horror-struck & 46. Role-playing \\
\hline 3. Chain-link & 25. Ice-cold & 47. Satin-smooth \\
\hline 4. Clear-cut & 26. Knee-jerk & 48. Self-conscious \\
\hline 5. Crinkly-eyed & 27. Make-believe & 49. Self-control \\
\hline 6. Cross-examination & 28. Middle-aged & 50. Self-defense \\
\hline 7. Cut-off & 29. Mile-long & 51. Self-esteem \\
\hline 8. Deep-voiced & 30. Mind-boggling & 52. Silent-movie \\
\hline 9. Dream-catcher & 31. Mind-numbing & 53. Sleep-talking \\
\hline 10. Dress-up & 32. Mind-reading & 54. Small-town \\
\hline 11. Full-sized & 33. Near-constant & 55. Snowy-white \\
\hline 12. Gauze-wrapped & 34. Near-death & 56. Still-sleeping \\
\hline 13. Gray-green & 35. Off-season & 57. Three-seat \\
\hline 14. Green-swathed & 36. Off-white & 58. Three-way \\
\hline 15. Half-crouched & 37. Olive-toned & 59. Tongue-tied \\
\hline 16. Half-fearful & 38. One-man & 60. Translucent-looking \\
\hline 17. Half-ran & 39. Open-ended & 61. Up-tempo \\
\hline 18. Half-smiled & 40. Pale-face & 62. Visitor-friendly \\
\hline 19. Half-truths & 41. Pastel-patterned & 63. White-blue \\
\hline 20. Hand-eye & 42. Pop-up & 64. Wide-eyed \\
\hline 21. Hard-muscled & 43. Rage-induced & 65. Wild-goose chase \\
\hline 22. Hate-filled & 44. Red-brown & \\
\hline \multicolumn{3}{|c|}{ Close Form of Compound Words } \\
\hline 1. Absentminded & 62. Eavesdropped & 123. Scholarship \\
\hline 2. Airborne & 63. Extraordinary & 124. Secondhand \\
\hline 3. Airbrushed & 64. Eyelids & 125. Shamefaced \\
\hline 4. Airport & 65. Eyepiece & 126. Shoebox \\
\hline 5. Audiovisual & 66. Eyesight & 127. Shotgun \\
\hline 6. Awestruck & 67. Farewell & 128. Sidestepped \\
\hline 7. Babysitter & 68. Footfall & 129. Sidetracked \\
\hline 8. Background & 69. Forefinger & 130. Sidewalk \\
\hline 9. Backlog & 70. Forehead & 131. Snowball \\
\hline 10. Backpack & 71. Fulltime & 132. Snowfall \\
\hline 11. Backpedaled & 72. Girlfriend & 133. Spellbound \\
\hline 12. Backseat & 73. Godlike & 134. Spotlight \\
\hline 13. Backyard & 74. Goodbye & 135. Staircase \\
\hline 14. Ballroom & 75. Grandparents & 136. Standstill \\
\hline 15. Barefoot & 76. Hairline & 137. Storyteller \\
\hline
\end{tabular}




\begin{tabular}{|c|c|c|}
\hline 16. Baseball & 77. Halfhearted & 138. Straightforward \\
\hline 17. Bathroom & 78. Handwritten & 139. Streetlamps \\
\hline 18. Bedroom & 79. Hard top & 140. Subsided \\
\hline 19. Bedspread & 80. Harebrained & 141. Suitcase \\
\hline 20. Bedtime & 81. Haystack & 142. Sunbathing \\
\hline 21. Birthday & 82. Headlight & 143. Sundown \\
\hline 22. Blackboard & 83. Headphone & 144. Sunglasses \\
\hline 23. Blacktop & 84. Heartbeat & 145. Sunlight \\
\hline 24. Bloodlust & 85. Heartbreaking & 146. Sunsets \\
\hline 25. Bloodstained & 86. Heavyset & 147. Sunshine \\
\hline 26. Bloodstream & 87. Hemlock & 148. Superhero \\
\hline 27. Boardwalk & 88. Homemade & 149. Supermarket \\
\hline 28. Bookmark & 89. Homesick & 150. Supervision \\
\hline 29. Bookstore & 90. Hometown & 151. Sweetheart \\
\hline 30. Boyfriend & 91. Homework & 152. Swimsuit \\
\hline 31. Brandishing & 92. Jackhammer & 153. Tabletop \\
\hline 32. Breadstick & 93. Keypad & 154. Taillights \\
\hline 33. Breakfast & 94. Lifetime & 155. Teammate \\
\hline 34. Breathtaking & 95. Lightheaded & 156. Thanksgiving \\
\hline 35. Butterflies & 96. Lighthearted & 157. Threshold \\
\hline 36. Butterscotch & 97. Lunchroom & 158. Thunderstorm \\
\hline 37. Cardboard & 98. Mailbox & 159. Tiptoes \\
\hline 38. Catlike & 99. Microscope & 160. Toothpaste \\
\hline 39. Cheekbone & 100. Microwave & 161. Townsfolk \\
\hline 40. Cheerleader & 101. Midday & 162. Treetops \\
\hline 41. Childhood & 102. Midnight & 163. Turtleneck \\
\hline 42. Chitchat & 103. Midway & 164. Uplifting \\
\hline 43. Classmate & 104. Minefield & 165. Upraised \\
\hline 44. Classroom & 105. Mouthwatering & 166. Upright \\
\hline 45. Cobwebs & 106. Mushroom & 167. Upset \\
\hline 46. Collarbone & 107. Nameplate & 168. Upward \\
\hline 47. Companionship & 108. Newcomer & 169. Warehouse \\
\hline 48. Cupboard & 109. Nickname & 170. Waterproof \\
\hline 49. Dashboard & 110. Nightfall & 171. Weatherman \\
\hline 50. Daydreaming & 111. Notebook & 172. Weatherproof \\
\hline 51. Daytime & 112. Offhand & 173. Weekend \\
\hline 52. Deathbed & 113. Openmouthed & 174. Werewolves \\
\hline 53. Dishrags & 114. Padlocked & 175. Wheelchair \\
\hline 54. Dishwasher & 115. Paperwork & 176. Whiteboard \\
\hline 55. Doorbell & 116. Pillowcase & 177. Wholehearted \\
\hline 56. Doorstep & 117. Pinpoint & 178. Wildflower \\
\hline 57. Doorway & 118. Pitchforks & 179. Willpower \\
\hline 58. Downpour & 119. Ponytail & 180. Windshield \\
\hline
\end{tabular}

Journal on English as a Foreign Language, 6(1), 59-70

Copyright @ 2016 by JEFL, p-ISSN 2088-1657; e-ISSN 2502-6615 


\begin{tabular}{lll}
\hline 59. Dreamlike & 120. Raincoat & 181. Withdrawn \\
\hline 60. Driftwood & 121. Redheaded & 182. Woolgathering \\
\hline 61. Earsplitting & 122. Runway & 183. Worksheet \\
\hline
\end{tabular}

\section{DISCUSSION}

The Twilight novel written by Stephenie Meyer has been analyzed about the compound words (Mayer, 2005). Compound words have many perspectives, but only three perspectives that is analyzed, such as written perspective, word class perspective and meaning perspective.

This study conducted was underlined by the theory taken from Delahuntly, Garvey, Murty, and Katamba. It is said that compound word has 3 forms: the closed form, compounds written as single words (newspaper, goldfish, highway); the hyphenated form, compounds that are hyphenated (mother-in-law, second-rate, court-martial); the open form, compounds written as separated words (end zone, high school, health care). The study has found open form words $1.9 \%$ such as an open book, high school, and etcetera; hyphenated form words $25.8 \%$ such as tired-looking, blow-dry, and etcetera; and closed form words $72.3 \%$ such as a daydream, breakfast, and etcetera.

Additionally, according to O'grady and Dobrovolsky theory, compounding differs from language to language, while the practice in English deals with the combination of some lexical categories, such as nouns, adjective, verbs or preposition in which the right most morpheme is called as the head that determines the category of a compounding. O'grady and Dobrovolsky mention no combination of preposition and preposition, verb and preposition, and noun and preposition.

\section{The Compound Noun Words Found (68.5\%)}

My mother drove me to the airport with the windows rolled down.

Air (noun) + port (noun) $\Rightarrow$ airport (noun)

Udara + pelabuhan $\Rightarrow$ bandar udara

Ibuku mengantarkanku ke bandar udara dengan jendela mobil menuru.

Based on the contextual meaning, the function of the word airport is as a noun which explained about the place for the plane land and takes off, usually with facilities for passengers and goods, and customs.

\section{The Compound Verb Words Found (5.2\%)}

"Yes, when the weather is good they go backpacking all the time - even the doctor." 
Back (noun) + pack (noun) $\Rightarrow$ backpacking (verb)

Punggung/bagian belakang + bungkusan $\Rightarrow$ bepergian menggunakan ransel punggung

"Ya, ketika cuaca baik mereka bepergian sepanjang waktu-bahkan dokternya."

Based on the contextual meaning above, the function of the word backpacking is a verb which explained about traveling somewhere using a backpack.

\section{The Compound Adjective Words (26.3\%)}

It was still the gray-green light of a cloudy day in the forest, but it was clearer somehow.

Gray (adjective) + green (adjective) $\Rightarrow$ gray-green (adjective)

Abu-abu + hijau $\Rightarrow a b u-a b u$ kehijauan (mendung)

Cahayanya masih abu-abu kehijauan dihari yang mendung dihutan, tapi kali ini lebih bersih bagaimanapun juga.

Based on the contextual meaning, the function of the word gray-green is an adjective which explained the word lightly, that was in the cloudy day.

Based on the theory of related literature in meaning perspective, this study used Nigel Fabb theory that divided compound into 2 classes. The exocentric compound is compounds without a head. Endocentric compounds are compounds which have a head.

\section{The Exocentric Compound Words Found (140 Words)}

A small town named Forks exists under a near-constant cover of clouds.

In contextual meaning, near-constant means within a short distance of time happen again and again. It is connotation which Forks is the cover of clouds. This word is an exocentric compound which the meaning of each word has no meaning with the meaning of the word near-constant.

\section{The Endocentric Compound Words Found (113 Words)}

There was only one small bathroom at the top of the stairs, which I would have to share with Charlie.

In the dictionary, bathroom means a room in which there is a bath, and also usually a wash-basin and a toilet. It is denotation in a context which she mentioned the room for taking a bath. The bathroom is endocentric compound and room as a stressing line of its word which explain about a place that has its own walls for washing the whole body. 


\section{CONCLUSION}

Based on the data findings and analysis found compound words in Twilight novel written by Stephenie Meyer, it has been found 253 compound words. In this part, this study analyzed to focus on the written perspective, word class perspective and meaning perspective.

First, according to Delahuntly, Garvey, JD. Murty and Katamba's theory, there are three forms of compound words such as open-form compound word, hyphenated form compound word, and closed-form compound words. This study found $1.9 \%$ or 5 open compound words, $25.8 \%$ or 65 hyphenated compound words and $72.3 \%$ or 183 closed compound words. The compound words have found $253(100 \%)$ in total.

Second, it is based on the word class perspective, according to O'grady and Dobrovolsky's theory, there are three words that are compound words, such as compound noun, compound verb, and compound adjective. In a compound noun found $68.5 \%$ or 173 words, in compound verb found $5.2 \%$ or 13 words and in a compound adjective found $26.3 \%$ or 67 words. The compound words have found $253(100 \%)$ in total.

Finally, it is based on the meaning perspective, according to Nigel Fabb's theory, there are two classes of meaning in compound words, such as exocentric compound and endocentric compound. This study used lexical meaning and contextual meaning in qualify the meaning of compound words. There are $55.3 \%$ or 140 words in exocentric compound words meaning and $44.7 \%$ or 113 words in endocentric compound meaning. The compound words have found $253(100 \%)$ in total.

\section{REFERENCES}

Aryana, L. W. (2008). Analisis hyphenated compound word dalam novel the trumpetmajor karya Thomas Hardy: Satu kajian morfologis. Thesis. Bandung: Widyatama University. (Online), Retrieved on 2013 from http://repository.widyatama.ac.id/handle/123456789/4017

Ginting, E. P. (2011). Analisis psikologis tokoh utama masako dalam novel "princess masako" karya Benn Hills. Medan: Universitas Sumatera Utara. (Online), Retrieved on 2013 from http://repository.usu.ac.id/handle/123456789/29537.

Gunawan, I. (2014). Metode penelitian kualitatif teori dan praktik. Jakarta: Bumi Aksara.

Haspelmath, M., \& Sims, A. D. (2010). Understanding morphology (2 ${ }^{\text {nd }}$ ed.). Hachette: Hachette UK Company.

Indihadi, D. (2012). Media dan alat peraga dalam pembelajaran bahasa kedua. (Online), Retrieved on 2013 from http:/file.upi.edu/direktori/dual- 
modes/pembinaan_bahasa_indonesia_sebagai_bahasa_kedua/13_bbm_1 1.pdf

McCarthy, A. C. (2002). An introducing to English morphology, Edinburgh: Edinburgh University Press Ltd.

Meyer, S. (2005). Twilight. New York: Hachette Book Group USA.

Sugiyono. (2010). memahami penelitian kualitatif. Bandung: Alfabeta.

Thompson, B. (1994). Advance in social science methodology. JAI Press. (Online). Retrieved from (http://de52f7gcctr69.cloudfront.net/process.php).

\section{Author's Brief CV}

Ririn Dwi Cahyanti got her degree of Sarjana Pendidikan Bahasa Inggris from IAIN Palangka Raya in 2015. She is interested in the development of English teaching and Literature. Now, she is teaching English at MA Hidayatul Insan Palangka Raya Kalimantan Tengah. 
